\title{
A Juridical Review of The Sultanate Lands and Villager Land Under The Governor Regulation Number 32 of 2007 on The Use of Villager Land After The Enactment of Act No. 6 of 2014 on Village
}

\author{
Damar Dwi Kuncoro ${ }^{1}$, Suroto ${ }^{2}$ and Amin Purnawan ${ }^{3}$
}

Abstract. The background of this research was the issuance of Act No. 6 Of 2014 about the Village. In one of its provisions contains the wealth of the village in the form of land certified on behalf of the Village Government. While the status of Villager Land in the Special Region of Yogyakarta is the land of the Sultanate. The research aimed to get an explanation of the status of Villager Land and to know the legal consequences that will arise with respect to the utilization of the Sultanate land associated with the Villager Land after the enactment of Act No. 6 of 2014, when associated with the Provincial Governor Regulation No. 34 of 2017 on Utilization of Villager Land. This research used sociological juridical approach (primary data) and direct interviews to the community in Sleman Yogyakarta (secondary data) and literature study. The result of the research shows that with the enactment of the Yogyakarta Governor Regulation, the Villager Land that comes from the right of anggaduh (Javanese Lng.) and the substitute land has been certified on behalf of the Village Government for the transfer of rights to the property of the Sultanate. Determination of the Sultanate as a Legal Entity which can become the subject of land ownership resulted in a change of status of the Sultanate institution to be equivalent to the private Legal Entity. The consequences of such changes resulted in changes in the management of the Sultanate land and the burden of obligations and responsibilities that must be met by the Sultanate for the management of the Sultanate land.

Keywords: Juridical Review; Sultanate land; Villager Land

\section{Introduction}

The village has the right of origin and the traditional right to organize and manage the interests of the local community and play a role in realizing the ideals of independence under the Constitution of the Republic of Indonesia Of 1945. In the state administrative of the Republic of Indonesia, the village has developed in various forms so it needs to be protected and empowered in order to be strong, advanced, independent and democratic. Thus, it can create a strong foundation in implementing

\footnotetext{
${ }^{1}$ Student of Master Program in Notary Program Students of Master of Law, Faculty of Law, Universitas Islam Sultan Agung email dam.dika88@gmail.com

2 Students of Master of Law, Faculty of Law, Universitas Islam Sultan Agung email murodtop76@gmail.com

${ }^{3}$ Lecturer of Faculty of Law UNISSULA
} 
governance and development towards a just, prosperous and welfare society ${ }^{4}$. Villages in the structure and procedures of governance and development need to be regulated separately by law. Based on these considerations, it is legalized and issued Act No. 6 Of 2014 on Village. One of the articles regulates the land, namely Article 76 paragraph (4) of Act No. 6 of 2014 on the Village which states that: "Wealth belonging to the Village in the form of land is certified on behalf of the Village Government". Act No. 6 of 2014 concerning Villages in Article 76 paragraph (4), states that the "village government obtains ownership of the land", in other words the village cash lands will belong to the village government not belong to the state. However, this will not apply to certain provinces such as the Special Territory of Yogyakarta. With regard to land tenure, in principle, it is entirely within the control of the government or the state. This is related to the control of the state of all state assets including in the land owned by the community.. ${ }^{5}$

Based on the background of the above problem, then the issue of this journal is how the status of Villager Land after the enactment of Act No. 6 of 2014 on the Village, when associated with the Governor Regulation Special Region of Yogyakarta (DIY) No. 34 of 2017 on Utilization Villager Land and any legal consequences that will arise in connection with the utilization of the sultanate's land associated with the Villager Land after the coming into effect of Act No. 6 Of 2014 on the Village, when associated with the Governor Regulation of Special Region of Yogyakarta No. 34 of 2017 on Utilization of Villager Land.

\section{Research Methods}

This study used several methods with the intention to be more easily in the analysis. This research used social legal research approach, Tamahana stated that socio-legal studies are addressed to Law and Society Studies ${ }^{6}$. It is using method of science also see reality in field especially in exploiting of Villager Land especially in Special Region of Yogyakarta. The type of research includes as Doctrinal/Normative Law Research which was the study of the Governor Regulation Number 34 Of 2017 concerning Land Utilization which is not in harmony with Act No. 6 Of 2014 on Village. Non-doctrinal Research/socio-legal research examined the Utilization of Villager Land in Yogyakarta Special Region.

This research is descriptive analysis, which aimed to find out and determine the relationship between data obtained from research with the foundation of existing theory. Data collection technique aimed to obtain primary data and secondary data which will then be analyzed. Primary data and secondary data can be obtained in data collection techniques that were Observation and direct interview to the community in

\footnotetext{
${ }^{4}$ Directorate General of Capture Fisheries Ministry of Maritime Affairs and Fisheries 2014 Law of the Republic of Indonesia Number 6 of 2014 concerning Villages Secretariat of the Directorate General of Capture Fisheries Ministry of Maritime Affairs and Fisheries Jakarta p.1 ${ }^{5}$ Soediono M. P. Tjondronegoro \& Gunawan Wiradi 1984 Dua Abad Penguasaan TanahPola Penguasaan Tanah Pertanian di Jawa dari Masa ke Masa PT.Gramedia Jakarta p. 10 ${ }^{6}$ Anis Mashdurohatun Redyanto Sidji Gunarto and Mahmutarom Factors Causing Banking Cyber Crime in Indonesian International Journal of Economic Research Volume 14 Number 152017 p.295
} 
Sleman Yogyakarta regency regarding the governor's regulation on the utilization of Villager Land after the enactment of Act No. 6 of 2014. The library studies is the activity of collecting various types of secondary data that was done with how to study and cite data from various documents, study and cite various information from the internet and print media on Villager Land and its utilization.

\section{Result And Discussion}

\subsection{Status of Villager Land after the enactment of Act No. 6 Of 2014 about the Village, when it is attributed to the Governor Regulation of Special Region of Yogyakarta (DIY) Number 34 Of 2017 About Utilization of Villager Land}

As it is known that the Special Region of Yogyakarta, formed from the merger of Sultanate and Pakualaman, then all the land in its territory belongs to the king. On the other hand, the public only has the right to utilize/right hereditary. After the issuance of Act No. 3 of 1950 on the Establishment of the Special Region of Yogyakarta which contains the provisions on the affairs of the household that became the authority of the Special Region of Yogyakarta. Some points which became the authority of the Special Region of Yogyakarta is the agrarian affairs, in order to execute the affairs issued the Regional Regulations governing the problems of land, which is wrong the only one is Local Regulation no. 5 of 1954. In Article 4 paragraph (1) of Regulation no. 5 of 1954 contains a provision which reads: " Special Region of Yogyakarta grants private property of hereditary (erfelijk individualueel bezitsrecht) on a plot of land to the citizens of the Republic of Indonesia hereinafter referred to as right of ownership" Administratively, generally, Sultanate lands are not recorded in the Register Book or in Letter $\mathrm{C}$ in the Village, because at the time of registration or recording were listed only the land used by the community. Land that has not been used by the community is only marked in the map according to its existence or its utilization at the time of mapping and registration, for example wedi kengser is for land on the river banks, pangonan is for land provided for grazing area, oro-oro is for land that has not utilized in the mountainous area of Gunungkidul, and gisir pasir land located along the southern sea. In accordance with existing data on the Regional Office of National Land Agency and Land Office, the implementation of measurement and mapping with registration in the register book for land within the municipality and the making of Letter A, Letter B and Letter C for land outside the municipal territory was conducted between 1926 and 1937.

In general, people recognize land that has not been controlled by a person with property rights or adarbe (before the law in Yogyakarta) as the property of Sultanate (Sultanate/Kadipaten). Therefore, in the case of people utilizing these lands they realize that it is not the land of their rights. Many people may use the lands of the Sultanate for the benefit of residential or business on the Sultanate land by applying permission to the Sultanate through Paniti Kismo with Magersari or Ngindung system. 
The utilization of the Sultanate land which is accompanied by a permit or grant from the palace shows that the de facto community recognizes the existence of the Sultanate land.

Management and utilization of the sultanate land in accordance with the provisions of Act No. 13 of 2012 Article 33 and Special Regulation No. 1 of 2013 Article 47 paragraph (3), it is stipulated that the management and utilization of the Sultanate and Kadipaten land shall be conducted in accordance with the laws and regulations. Thus, technically for the management of the Sultanate land will follow the provisions of Act No. 5 of 1960 and its implementing regulations.

In the framework of the first registration of the land of the Sultanate performed the stages of activity was the inventory of objects undertaken jointly between the Sultanate, Land Office, Village Government the location of the Sultanate land, third parties who utilize the land of the Sultanate and the Government of Yogyakarta Special Region as implementing activities related to the Region By registering through the process of recognition of rights. The book of rights and the issuance of certificate of Right to the Land of the Sultanate, concerning the utilization of Sultanate land by a third party with the status of land as land of Property, the utilization of the Sultanate land by a third party are carried out with the imposition of rights in the presence of the land certificate official (PPAT). In relation to the status of the Sultanate as a legal entity equivalent to a private legal entity, the Sultanate shall be subject to the obligation as the other legal entity, namely for the utilization of land by a third party giving the income contribution in the Sultanate will be subject to the payment of income tax. Apart from that for land not used by other parties, the obligation to pay the land tax and building must be the obligation of the Sultanate.

\subsection{Legal Consequences that Will Arise With regard to the Utilization of Sultanate Land Related to the Villager Land After the enactment of Act No. 6 Of 2014 About the Village, When It Is Attributed to the Governor Regulation of Special Region of Yogyakarta (DIY) Number 34 Of 2017 About Utilization of Villager Land}

The consequences will arise with respect to the utilization of the sultanate's land associated with Villager Land after the coming into effect of Act No. 6 Of 2014, when it is associated with the Governor Regulation of Yogyakarta Special Region No. 34 of 2017 on the use of Villager Land. According to Mr Anggit, interviewee from Madurejo Village, Yogyakarta Villages, the transfer of title of the Villager Land certificate from the village belongs to the Legal Entity of Sultanate/Pakualaman, after the issuance of Governor Regulation No. 34 of 2017 on the utilization of Villager Land, is ordered the Village Government through the Regent/Mayor to make a request behind the name of the village title certificate. The land certificate that has been issued from the right of the Village Government belongs to the Legal Entity of Cultural Heritage of Sultanate/Kadipaten Pakualaman. Making almost all the Villager Land in Yogyakarta belongs to the Sultanate is certified on behalf of the Sultanate and the village has no assets because the village only obtains the right of Anggaduh. Even though, there has been Act No. 6 of 2014 concerning the Village mandating. The village treasury is the 
village's wealth which must be certified to belong to the village as a legal entity. However, the Governor does not want Villager Land to belong to the village unless the village buys land through PAD (Original Revenue Village) the land will become the Village Asset

The licensing of non-agricultural Villager Land use is mandatory through the Sultanate, the utilization of Villager Land in Yogyakarta, especially non-agriculture such as Factory or Cultural Tourism, besides requesting permission to the One Stop Service (PTSP) Investment Service Department, the Sultanate also participate in the permit. The Sultanate will survey whether the use of the village is feasible or not to be carried out, even though the village community and the One Stop Service (PTSP) Investment and Service Department approve it. The Sultanate also provides a period for the utilization of Villager Land used as a Factory or Cultural Tour (non-farm). Act No. 6 of 2014 on Village Chapter IV article 18 explains "The Village Authority includes the authority in the field of Village Governance, the implementation of Village Development, Village Community Development, and Village Community Empowerment based on community initiatives, village rights and village customs". Therefore, it is clear that the Village Development or Utilization is the absolute authority of the Village, but Act No. 6 of 2014 on the Village does not apply in the Special Region of Yogyakarta.

The certification of Villager Land belongs to the Sultan's legal entity, conducted data collection and registration of state lands, ie land that has not been certified in the whole of Yogyakarta Special Region to be owned by Sultanate as a private legal entity using APBN (State Budget) fund, including: forest, wedi kengser, and Villager Land. And re-examination of the origin of land that has become the property of the community according to Rijksblad Number 16 of 1918, if it is proven in 1918 that the land is not certified the right of ownership (eigendom) then the land will switch ownership; of the Community Property belongs to the Sultanate/Pakualaman Property.

\section{Clossing}

\subsection{Conclusion}

- The right to utilize the Villager Land based on the Governor Regulation of Daerah Istimewa Yogyakarta (DIY) Number 34 Of 2017 on the Utilization of Villager Land, that with the enactment of the Governor Regulation, the Villager Land derived from the subsistence rights and replacement land that has been certified on behalf of the Village Government to do the transfer of rights to the property of the Sultanate and/ or the land owned by the Kadipaten.

- Legal consequences arising in connection with the utilization of the sultanate land associated with Villager Land after the enactment of Act No. 6 Of 2014 on the Village. When it is associated with the Governor Regulation of Yogyakarta Special Region (DIY) No. 34 of 2017 on Utilization of Villager Land include the following: behind the name of the Villager Land Certificate from the village belongs to the legal entity of Sultanate/Pakualaman, licensing of non-agricultural Villager Land use through the Sultanate, Villager Land certification belongs to the Sultan's legal entity 


\subsection{Suggestion}

- For the public, the importance of general knowledge about the science of law and the relationship between the communities with the Sultanate should be able to synergize well so as to create a good relationship and information can run well in accordance with legislation.

- For State/Officials in making and compiling government policies, it should be noted that there are policies that cannot be applied in the Special Region of Yogyakarta, especially on land because the soil history is different.

\section{References}

[1] Anis Mashdurohatun Redyanto Sidji Gunarto and Mahmutarom Factors Causing Banking Cyber Crime in Indonesian International Journal of Economic Research Volume 14 Number 152017

[2] Baskoro Haryadi dan Sunaryo Sudomo 2010 Catatan Perjalanan Keistimewaan Yogya : Merunut Sejarah Mencermati Perubahan Menggagas Masa Depan Pustaka Pelajar Yogyakarta.

[3] Dwiyanto Djoko 2009 Kraton Yogyakarta. Sejarah Nasionalisme \& Teladan Perjuangan ParadigmaYogyakarta Yogyakarta.

[4] Fauzi M dkk 2010 kronik Agraria Indonesia STPN PRESS Yogyakarta.

[5] Suriangka Andi 2013 Pendaftaran Hak Pakai Atas Tanah Jurnal Al-Risalah Vol.13 Nomor 1 Mei 2013. 